J. Koshak, Ph.D. in Technology, Associate Professor, Head of the Feed Laboratory, E-mail: Koshak.zn@Gmail.com

N. Zenovich, Graduate Student, Researcher, E-mail: nata.zenovich@mail.ru

E. Rybkina, Master Student, Junior Researcher, E-mail: evgesha.rybkina.97@mail.ru Scientific and Practical Center of the National Academy of Sciences of Belarus for Livestock RUE, Institute of Fisheries RUE, Stebneva Str.,, 22, Minsk, Republic of Belarus, 220024

\title{
THE IMPACT OF PRODUCTION TREATMENTS OF FEED CONCENTRATE PRODUCED FROM WASTE OF CEREAL PRODUCTION ON ITS BIOLOGICAL VALUE AND EFFICIENCY IN THE COMPOSITION OF COMPOUND FEED FOR CARP
}

\begin{abstract}
The following article presents a new raw component in compound feed for carp - feed concentrate produced from cereal production waste. The feed concentrate is based on several types of cereal fodder meal - wheat, pea, barley, as well as wheat bran and unshelled oat grain. The feed concentrate is balanced according to the needs of carp and can be used as feed for carp instead of wheat grain or as a part of compound feed for carp. Heat-moisture processing of compound feed before extrusion is one of the main stages that further ensure the stability of technological processes and the final quality of the feed concentrate. The amino acid composition was determined at various temperatures of the feed concentrate after heat-moisture treatment of $+40,60,70$ and $80^{\circ} \mathrm{C}$ at a constant moisture content of the concentrate of $+28 \pm 2{ }^{\circ} \mathrm{C}$. Amino acid score has been calculated for feed concentrates that have been exposed to various heat treatments. The amino score was calculated in relation to the carp's need for essential amino acids. It was found that an increase in the temperature of the concentrate during heat-moisture treatment leads to a decrease in the content of essential amino acids. For example, the total content of methionine and cysteine in the composition of the feed concentrate at a temperature of $+75^{\circ} \mathrm{C}$ was $0.46 \%$, with the minimum allowable total content of these amino acids in the composition of feed $0,5 \%$. Heat-moisture treatment at a product temperature above $+75^{\circ} \mathrm{C}$ leads to a decrease in the content of essential amino acids and the biological value of the feed concentrate.

The process of extrusion of feed concentrate from waste of cereal production has been studied. The glucose content in the feed concentrate was studied at various extrusion modes. The glucose content indicates the degree of modification of the starch during the extrusion process, and the more glucose the product contains, the better it is absorbed by the carp. When extruded with an increase in temperature, the starch passes into a viscous-flowing (gelatinized) state, forming a so-called melt, the cooling of which also leads to the formation of a three-dimensional gel network. The feed concentrate granule becomes monolithic in structure; it becomes quite hard and can harm the intestines of carp. Therefore, it contains wheat bran in an amount of 1\%, as a component that is able to weaken the feed concentrate granule. The degree of starch destruction in the composition of the extruded feed concentrate with the addition of wheat bran reached its maximum and the granule became porous, its hardness decreased. It was detected that when the temperature of the feed concentrate after extrusion rises above $+100^{\circ} \mathrm{C}$, the biological value of the feed concentrate decreases, and it becomes unbalanced in the content of such essential amino acids as lysine, threonine, methionine and cysteine. Therefore, the optimum product temperature after extrusion is $+90-100^{\circ} \mathrm{C}$.

The effectiveness of extruded feed concentrate was determined in the composition of granulated feed for two- and threeyear-old carp. The feed ratio of the compound feed containing the feed concentrate was 0.9 units, which is $64 \%$ lower than of the control compound feed, which includes a non-extruded grain group that is not balanced in terms of carp needs.
\end{abstract}

Key words: feed concentrate, fodder meal, oats, carp, extrusion, granulation, heat-moisture treatment, amino acid score.

\section{Introduction}

Carp is the main object of cultivation in the Republic of Belarus. In 2020, the volume of carp cultivation amounted to about 18 thousand tons. To cultivate such volume, more than 50 thousand tons of compound feed and more than 100 thousand tons of grain are needed. Abroad, a minimum amount of grain is used as part of compound feed, and secondary products of food production, including secondary products of cereal production, are used to the maximum [1].

Fodder meal is obtained by processing grain of various crops into cereals. It consists mainly of grain particles, fruit and seed coats, germs and aleurone layer obtained by peeling, grinding, polishing grain in the production of cereals. Fodder meal is a valuable nutritious product similar to grain in its properties. Fodder meal made from wheat and barley is of high value; the one produced from buckwheat is of a lesser value as it contains a lot of fiber and therefore has a lower digestibility level [2-4].

When cultivating marketable carp in pond fish farming, it is planned to use compound feeds with a crude protein content of at least $23 \%$. In addition to compound feed, carp also needs live feed, the content of which increases from the beginning of the growing season and then gradually decreases. Numerous studies back in the 20th century have established that if live food in the diet of carp is at least a third, then the quality of the 
additionally introduced food does not affect the fish culture indicators [5]. If we assume the proportion of live food in the ration of carp in the amount of 33\% and take into account the content of protein and essential amino acids in it, then it is enough to feed carp with low-protein and deficient in amino acid composition of food, for example, cereal grain [6]. However, fodder meal has a higher feed value in comparison with grain, wheat grain in particular. The developed composition of feed concentrate produced from cereal production wastes is a mixture of fodder meal, grain and bran, the balance of which is more complete for carp compared to wheat grain [7]. However, it is not enough to develop the composition - it is also necessary to select the parameters of the technological processes of production, which will preserve or improve the final composition of the feed concentrate.

In this regard, the Purpose of the Study is to select the optimal treatments for the production of feed concentrate from the waste of cereal production.

\section{Materials and methods}

The object of the study was feed concentrate obtained from cereal production waste. All experiments on the selection of the optimal parameters for the technological processes of heat-moisture treatment and extrusion were carried out on a scientific experimental line for the production of compound feed for fish. Biochemical analyzes were carried out in accordance with the current State Standards and approved methods of determination.

\section{Research results and their discussion}

The composition of the feed concentrate included types of fodder meal rich in protein and well absorbed by carp: wheat, barley, pea, as well as wheat bran and oat grain. The chemical composition of the cereal concentrate was determined before extrusion. See Tabl 1 for data.

The sequence of technological procedures for the production of feed concentrate includes the following stages: preparation of crude materials, grinding, dosing, mixing and extrusion. To preserve the biological value of the feed concentrate, it is necessary to select the extrusion modes, since they most significantly affect the biological value of the final product.

Extrusion is based on three processes: temperature treatment of feed under pressure;
- mechanochemical deformation;

- explosion of the product in the shock discharge

front.

During this process deep destructive changes in nutrients occur: starch is broken down to dextrins and sugars, proteins are denatured.

The scientific extrusion line consists of an air conditioner-mixer and an extruder. See Figure 1 for the external view of the laboratory equipment.

Heat-moisture treatment of compound feed (HMT) is one of the main stages that further ensure the stability of the technological processes and the final quality of compound feed and feed concentrates. HMT is necessary for a targeted impact on the nature and degree of both physical and chemical transformations of biopolymers of compound feed [8]. Therefore, it is necessary to select HMT modes in such a way as to reduce the negative effect of temperature and maintain a positive effect, which is expressed in an increase in the nutritional value of feed concentrate for carp.

In the course of the research, the following modes of heat-moisture treatment were selected:

- steam pressure $0.20 \mathrm{MPa}$;

- steam consumption 75 - $80 \mathrm{~kg} / \mathrm{t}$;

- product temperature after heat-moisture treatment of $+40,60,70$ and $80{ }^{\circ} \mathrm{C}$.

- moisture content of feed concentrate after heatmoisture treatment of $+28 \pm 2^{\circ} \mathrm{C}$

The amino acid score of the feed concentrate was calculated in relation to the needs of carp at different temperatures after heat-moisture treatment.

Lysine, leucine and isoleucine are some of the
Tabl 1 - Chemical Composition of the Feed Concentrate before extrusion

\begin{tabular}{||c||c|c|c||c||c||}
\hline \multirow{2}{*}{ Name } & \multicolumn{4}{|c|}{ Content, \% } \\
\cline { 2 - 6 } & humidity & dry matter & crude protein & crude fat & crude fiber \\
\hline \hline $\begin{array}{c}\text { Feed } \\
\text { Concentrate }\end{array}$ & $8,71 \pm 0,13$ & $91,21 \pm 0,13$ & $16,19 \pm 0,33$ & $1,36 \pm 0,34$ & $3,94 \pm 0,04$ \\
\hline
\end{tabular}

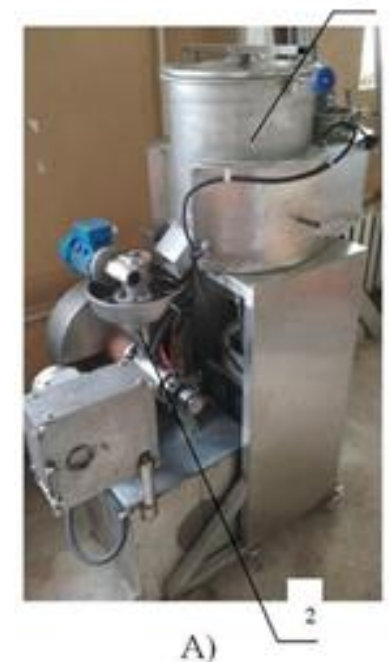

A)

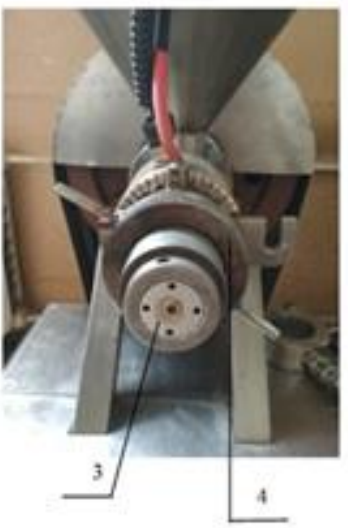

B)

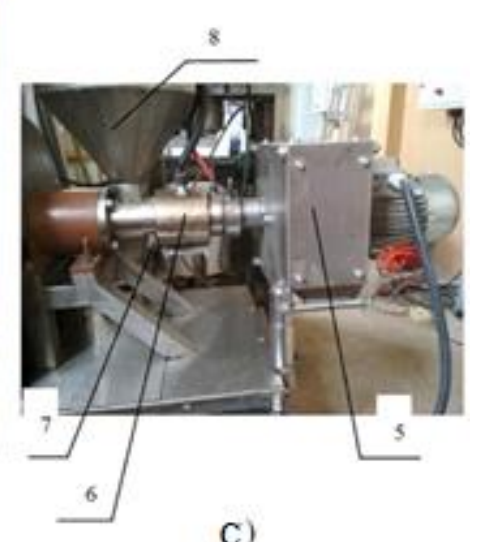

C)
A) Equipment for heat-moisture treatment and extrusion of compound feed:

1- Heat-moisture treatment unit; 2 - Extruder; B) Extruder pressing unit: 3 - Extruder die, $\varnothing 4 \mathrm{~mm} ; 4$ - Die fixing ring; C) Extruder side view: 5 - Blade unit for cutting feed pellets; 6 - Heating of the extruder barrel; 7 - Steam supply to the extruder barrel;

8 - Extruder feeder

Fig. 1. Laboratory Extrusion Equipment 


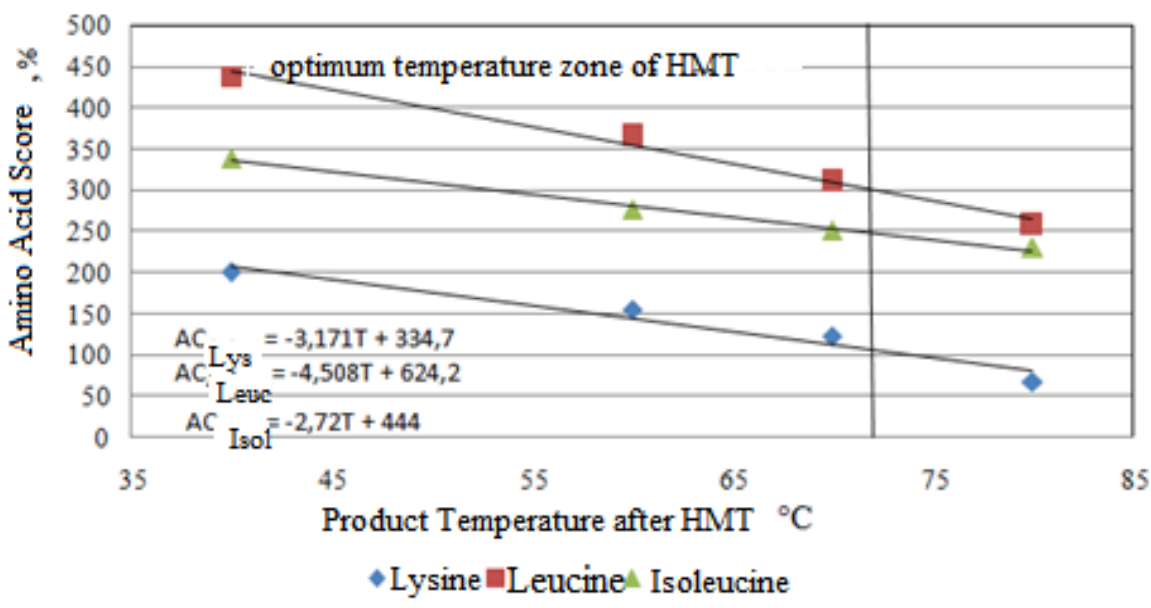

Fig. 2. Dependence of the Amino Acid Score of Lysine, Leucine and Isoleucine on the temperature of the feed concentrate after heat-moisture treatment

main essential amino acids in carp nutrition, therefore, the dependence of the amino acid score of these amino acids on the temperature of the feed concentrate after heat-moisture treatment was draw up (Figure 2 for Graphical Dependence).

Analyzing Figure 2, it can be observed that the optimal temperatures zone for heat-moisture treatment, at which the amino acid score in relation to the carp needs, is over $100 \%$ for lysine, leucine and isoleucine lies in the temperature range of $+70-72^{\circ} \mathrm{C}$. Heat-moisture treatment temperatures above $+65^{\circ} \mathrm{C}$ are necessary to increase the digestibility of grain crops, in our case, a feed concentrate based on cereal fodder meal. At these HMT temperatures of the product, part of the starch is converted into simpler forms of carbohydrates - dextrins, maltose. A partial denaturation of proteins can be observed as well, together with the destruction of a number of antinutritional components and other biochemical processes that increase the nutritional value of the feed concentrate.

For other essential amino acids, an increase in the temperature of the concentrate during heat-moisture treatment leads to a decrease in their content: the total content of methionine and cysteine in the composition of the feed concentrate at its temperature of $+75^{\circ} \mathrm{C}$ was $0.46 \%$, with the minimum allowable total content of these amino acids in the feed composition of $0,5 \%$. It was found that heat-moisture treatment at a product temperature above $+75^{\circ} \mathrm{C}$ leads to a decrease in the content of essential amino acids and the biological value of the feed concentrate.

The next stage, which significantly transforms the feed concentrate during its production, is the extrusion process itself. Extrusion involves heating the product in the barrel of the extruder due to frictional forces during movement, followed by pressing through the die holes. When passing through the barrel of the extruder, the product experiences a short-term exposure to high temperatures (up to $+200^{\circ} \mathrm{C}$ ). For this reason, despite the short-term exposure to high temperatures, significant biochemical changes will be observed in the feed concentrate.

The most important and basic changes occur in the extrusion zone with the rapid movement of the crude products from the high pressure zone $\left(16 \times 10^{5} \mathrm{~Pa}\right.$ or 15.8 atm. and more) to the atmospheric one. During this process, the energy accumulated in the product is released at the speed of an explosion, and completes structural transformations (rupture of cell walls, destruction and hydrolysis of biopolymers). It is also at this stage the product swells, a sharp increase in its volume and the formation of a porous structure takes place. Such hydrobarothermal treatment of the crude product contributes to multiple rupture of cell membranes, changes in the structure of starch and nonstarchy polysaccharides, partial denaturation of the protein and a change in its fractional composition, death of micro flora, inactivation of toxins. At this stage of research, a PFE $2^{3}$ with a stellar line was implemented. Screw speed, temperature and humidity of the product before extrusion were chosen as independent factors. One of the main indicators of changes in the biochemical composition of a product is the amount of glucose in the feed concentrate after extrusion. An analytical relation was obtained that describes the change in the amount of glucose in the feed concentrate depending on the rotational speed of the screw and the temperature of the product and the moisture content of the concentrate before extrusion, which has the following form:

$$
\begin{aligned}
& \mathrm{S}=1287,04+22,19 \cdot \mathrm{V}-1,76 \cdot \mathrm{T}-113,88 \cdot \mathrm{W}- \\
& 0,71 \cdot \mathrm{V}^{2}+0,18 \cdot \mathrm{V} \cdot \mathrm{T}+0,074 \cdot \mathrm{V} \cdot \mathrm{W}-0,13 \cdot \mathrm{T}^{2}+ \\
& 0,54 \cdot \mathrm{T} \cdot \mathrm{W}++1,64 \cdot \mathrm{W}^{2} \\
& \text { with } \mathrm{S}-\text { glucose amount, } \mathrm{mg} / \mathrm{g} ; \\
& \mathrm{V}-\text { extruder screw speed, } \mathrm{rpm} ; \\
& \mathrm{T}-\text { temperature of feed concentrate after HMT }
\end{aligned}
$$
before extrusion, ${ }^{\circ} \mathrm{C}$;

$\mathrm{W}$ - moisture content of feed concentrate before extrusion, \%.

Physicochemical properties of starch are determined by its polysaccharide composition, type of glycosidic bonds, molecular size, as well as strength and compactness. Unlike simple sugars, starch is poorly absorbed by fish. In contrast to most other biopolymers, the polysaccharide molecules that make up starch are not the same in chemical structure, although they consist of the same structural units. Both starch polysaccharides (amylose and amylopectin) differ significantly from each other not only in structure, but also in molecular weight.

Starch makes up $65 \%$ of the mass of dry feed concentrate, and in the process of thermoplastic extrusion under the influence of moisture, temperature, mechanical stress, it undergoes complex transformations; this leads to a change in its structural and mechanical properties. It has been detected that with a physicochemical effect on starch grains, it is possible to change their structure in any direction. In case of mechanical action on starch, the grains are most likely to rupture in a radical direction.

When extruded with an increase in temperature, the starch passes into a viscous-flowing (gelatinized) state, forming a so-called melt, the cooling of which 
leads to the formation of a three-dimensional gel network. The feed concentrate granule becomes monolithic in structure; it becomes quite hard and can harm the intestines of carp. Due to the above, in order to reduce the hardness of the starch paste, substances which are able to weaken the monolithic structure, such as salt, tripoli and bran, were introduced into the composition of the feed concentrate. The degree of starch destruction was determined in these samples of feed concentrate (Tabl 2 for data).

Tabl 2 - Degree of starch destruction in the composition of extruded feed concentrate based on cereal fodder meal with salt, tripoli and bran added

\begin{tabular}{||l|c||}
\hline \multicolumn{1}{|c|}{ Sample } & $\begin{array}{c}\text { Glucose Amount, } \\
\mathrm{mg} / \mathrm{g}\end{array}$ \\
\hline \hline $\begin{array}{l}\text { Extruded feed additive with added } \\
\text { salt }\end{array}$ & 109,84 \\
\hline \hline Extruded feed additive with tripoli & 109,28 \\
\hline \hline Extruded feed additive with bran & 131,50 \\
\hline
\end{tabular}

Analyzing the data of Tabl 2, it can be observed that the bran contributes in the best way to the destruction of starch grains and thereby reduces the hardness of the granules. See Figure 3 for the appearance of the extruded feed concentrate with the introduction of bran into its composition.

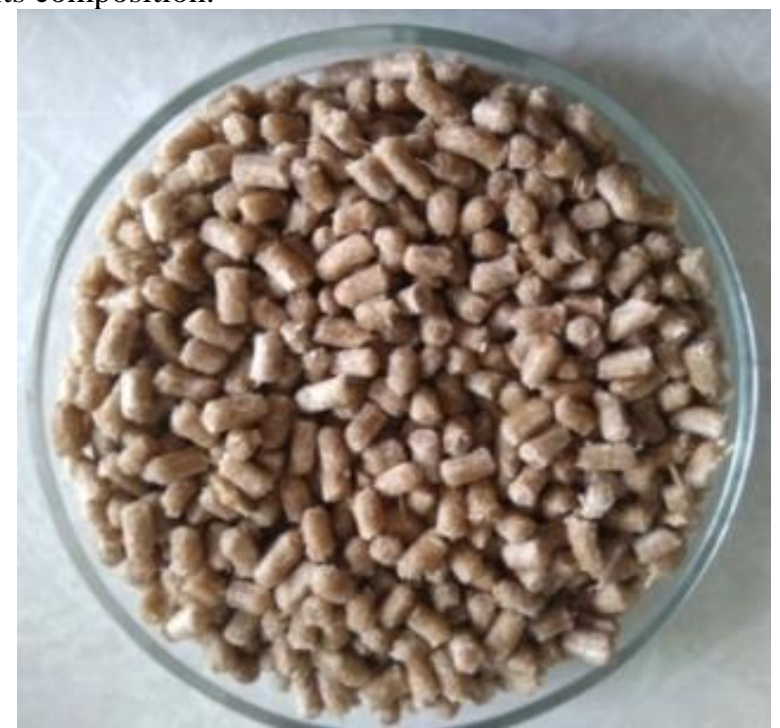

Fig. 3. Appearance of extruded feed concentrate with the inclusion of wheat bran

In the process of extrusion under the impact of temperatures, a decrease in the content of amino acids in the composition of the feed concentrate is observed. The amino acid score was determined for the main essential amino acids in the composition of the feed concentrate in relation to the needs of carp. See Tabl 3 for data.

Analyzing the data of Tabl 3, it can be observed that when the temperature of the feed concentrate after extrusion rises above $+100^{\circ} \mathrm{C}$, the biological value of the feed concentrate decreases, and it becomes unbalanced in the content of such essential amino acids as lysine, threonine, methionine and cysteine. Therefore, the optimum temperature range of the product after extrusion is +90 $100^{\circ} \mathrm{C}$.
Tabl 3 - Amino acid score of feed concentrate produced from cereal waste

\begin{tabular}{|c|c|c|c|c|}
\hline \multirow{2}{*}{ Amino acid } & \multicolumn{4}{|c|}{$\begin{array}{l}\text { Temperature of feed concen- } \\
\text { trate after extrusion, }{ }^{0} \mathrm{C} \\
\end{array}$} \\
\hline & 80 & 90 & 100 & 120 \\
\hline Lysine & 179 & 156 & 109 & 68 \\
\hline Threonine & 160 & 146 & 119 & 99 \\
\hline Methionine + Cysteine & 112 & 110 & 108 & 96 \\
\hline Valine & 370 & 365 & 258 & 218 \\
\hline Phenylalanine + Tyrosine & 457 & 457 & 346 & 330 \\
\hline Leucine & 406 & 395 & 341 & 257 \\
\hline Isoleucine & 325 & 271 & 268 & 252 \\
\hline
\end{tabular}

At the next stage of the research, the effectiveness of the feed concentrate in the composition of the granulated compound feed for two and three-year-old carp was determined. The quality indicators of compound feed are presented in Tabl 4.

Tabl 4 - Physicochemical indicators of compound feed K-111

\begin{tabular}{||l||c|}
\hline \multicolumn{1}{|c||}{ Indicator } & Contents, \% \\
\hline \hline Humidity & $8,64 \pm 0,32$ \\
\hline \hline Dry matter & $91,36 \pm 0,32$ \\
\hline \hline Crude protein & $24,01 \pm 0,54$ \\
\hline \hline Crude fat & $3,08 \pm 0,00$ \\
\hline \hline Crude fiber & $7,45 \pm 0,11$ \\
\hline
\end{tabular}

Analyzing the data of Chart 4, we can note that the quality indicators of the compound feed correspond to the current TS BY 100035627.028-2021 "Economical production compound feed for uneven-aged carp with the addition of dry enzymatic feed" Fekord-Aqua". This compound feed contains an extruded feed concentrate from wastes of cereal production and a new enzyme complex "Fekord Aqua", specially developed by the laboratory of fish feed.

To determine the influence of the granulation process of compound feed on its efficiency, an experimental feeding of carp was carried out. Fish food was given in the amount of $1.5-3.0 \%$ of the mass 3 times a day. The feed was counted daily. No fish loss was observed during the experiment.

The influence of the production of granulated compound feed under different HMT modes on the growth performance of carp is presented in Tabl 5.

Analyzing the data of Chart 5, it should be noted that the best indicators of the absolute growth of carp were shown by compound feed, which was produced with the following parameters of heat-moisture treatment: $\mathrm{W}_{\mathrm{K}}=16 \%$ and temperature of heat-moisture treatment $\mathrm{T}_{\mathrm{HMT}}=+80^{\circ} \mathrm{C}$, while the feed coefficient is 1.0 unit.

With an increase in the moisture content of the compound feed by $2 \%$, the feed ratio decreases to 0.9 units: this occurs due to the more durable granule and a 
Tabl 5 - Growth indicators of carp when feeding with compound feed

\begin{tabular}{|c|c|c|c|c|}
\hline \multirow[t]{2}{*}{ Heat-Moisture treatment Modes } & \multicolumn{2}{|r|}{ Growth of carp } & \multirow{2}{*}{$\begin{array}{c}\text { Feed } \\
\text { consumption, } \\
\mathrm{g} \\
\end{array}$} & \multirow{2}{*}{$\begin{array}{l}\text { Feed } \\
\text { ratio, } \\
\text { units } \\
\end{array}$} \\
\hline & absolute, $\mathrm{g}$ & relative to the original mass, $\%$ & & \\
\hline $\mathrm{W}_{\mathrm{K}}-16 \%$ and $\mathrm{T}_{\mathrm{HMT}}-+80^{\circ} \mathrm{C}$ & $2,25 \pm 0,48$ & $9,00 \pm 1,80$ & 35,2 & 1,0 \\
\hline $\mathrm{W}_{\mathrm{K}}-16 \%$ and $\mathrm{T}_{\mathrm{HMT}}-+85^{\circ} \mathrm{C}$ & $3,00 \pm 0,41$ & $7,98 \pm 1,52$ & 43,2 & 1,2 \\
\hline $\mathrm{W}_{\mathrm{K}}-18 \%$ and $\mathrm{T}_{\mathrm{HMT}}-+80^{\circ} \mathrm{C}$ & $1,70 \pm 0,48$ & $6,05 \pm 1,52$ & 60,2 & 0,9 \\
\hline $\mathrm{W}_{\mathrm{K}}-18 \%$ and $\mathrm{T}_{\mathrm{HMT}}-+85^{\circ} \mathrm{C}$ & $1,60 \pm 0,37$ & $3,63 \pm 0,75$ & 59,9 & 1,4 \\
\hline
\end{tabular}

Note: $\mathrm{W}_{\mathrm{K}}$ is the moisture content of the compound feed before granulation; $\mathrm{T}_{\mathrm{HMT}}$ - temperature of heat-moisture treatment

decrease in the loss of granules in the water when feeding carp. The feed ratios of the control compound feed, which did not contain feed concentrate, were 2.5 units per kilogram of carp gain under identical HMT modes $\left(\mathrm{W}_{\mathrm{K}}-18 \%\right.$ and $\left.\mathrm{T}_{\mathrm{HMT}}-+80^{\circ} \mathrm{C}\right)$, which is $64 \%$ higher.

\section{Conclusions}

The following study presents the results of the research of the production modes of feed concentrate and its effectiveness in the composition of compound feed for carp. The optimal temperature of heat-moisture treatment of feed concentrate before extrusion has been determined in the temperature range of $+70-72^{\circ} \mathrm{C}$, where the biological value of the product is preserved.

An analytical dependence is obtained that describes the change in the amount of glucose in the feed concentrate depending on the rotational speed of the extruder screw, temperature and moisture content of the concentrate before extrusion.
The degree of destruction of starch samples of feed concentrate was determined during extrusion, containing tripoli, salt and bran. It was found that in order to reduce the hardness of extruded granules, it is necessary to add $1 \%$ of wheat bran to the composition of the feed concentrate, while the degree of destruction is maximum in comparison with concentrates containing tripoli and salt.

An increase in the temperature of the feed concentrate after extrusion above $100^{\circ} \mathrm{C}$ leads to a decrease in the biological value of the feed concentrate; therefore, the optimal temperature of the concentrate after extrusion is $+90-100^{\circ} \mathrm{C}$.

Tests of compound feed containing feed concentrate were carried out. The smallest feed coefficients of the $\mathrm{K}-111$ compound feed were obtained at $\mathrm{W}_{\mathrm{K}}=18 \%$ and the temperature of the heat-moisture treatment $\mathrm{T}_{\mathrm{HMT}}$ $=+80{ }^{\circ} \mathrm{C}$, which are $64 \%$ lower than the feed coefficients of the control feed K-111.

\section{REFERENCES}

1. Sharshunov, V.A. Compound Feeds and Feed Additives [Text] /V.A. Sharshunov, N.A. Popkov, Yu.A. Ponomarenko et al. Minsk: "Ecoperspektiva", 2002. - 440.

2. Abrosimova, N. A. Fodder Crude Products for Aquaculture Facilities [Text] / N.A. Abrosimova, S.S. Abrosimov, E.M. Sayenko. - Rostov-on-Don: Everest, 2005 .-- 144.

3. Nikiforova, T.A. Prospects for the Use of Secondary Crude Products for Cereals [Text] / T.A. Nikiforova, S.M. Severinenko, D.A. Kulikov // Bread products. - 2009. - No. 7. - pp. 50-51.

4. Egorov, G.A. Technology of Flour, Cereals and Compound Feeds [Text] / G.A. Egorov, E.M. Melnikov, B.M. Maksimchuk. - M. Kolos, 1984 .-- 376.

5. Eleonsky, A.N. Pond Fish Farming: Permitted VKVSH at the Council of People's Commissars of the USSR as a textbook for technical schools of fish industry/ Biol. Sciences, D-r, Prof. A. N. Eleonsky; Moscow Tech. Institute of Fishes. Households and Industry A.I. Mikoyan. - Moscow: Pishchepromizdat, 1946 (Leningrad: Typ. "Printing House"). - 325.

6. Tomme, M.F. Amino Acid Composition of Feed / M. F. Tomme, Prof., R. V. Martynenko, Ph.D. Agricultural Sciences; Union Acad. Agricultural Sciences after V.I. Lenin. Animal Husbandry Dep. Union Scientific Research Institute of Animal Husbandry. - Moscow: Kolos, 1972 .-- 288; $22 \mathrm{~cm}$.

7. Koshak, Zh.V. New Cereal Additive Produces from Cereal Production Waste for Carp Underyearlings / Zh.V. Koshak, N.V. Zenovich, A.E. Koshak // Food Industry: Science and Technology. - 2019. - No. 4 (46). - Volume 12. - 38-48.

8. Darmanyan, P.M. Problems of Regulating the Quality of Granulated Compound Feeds and Their Components / P.M. Darmanyan // TsNIITEI Grain Products. - Compound Feed Industry. - 1993. - 52.

- -

УДК 636;639.3.043

Ж.В. Кошак, канд. техн. наук, доцент, зав. лабораторісю кормів, E-mail: Koshak.zn@ Gmail.com Н.В. Зенович, аспірант, наук. спіроб., E-mail: nata.zenovich@ mail.ru

Є.Є. Рибкіна, магістрант, мл. наук. співроб., E-mail: evgesha.rybkina.97@mail.ru РУП «Інститут рибного господарства» РУП «Науково-практичний центр Національної академії наук Беларусі з тваринництва», Республіка Беларусь

вул. Стебенєва 22, 220024, Мінск, Республіка Беларусь, Тел./факс +375 1735196 25, +375297806608

\section{ВПЛИВ РЕЖИМІВ ВИРОБНИЦТВА КОРМОВОГО КОНЦЕНТРАТУ 3 ВІД- ХОДІВ КРУП'ЯНИХ ВИРОБНИЦТВ НА ЙОГО БІОЛОГІЧНУ ЦІННІСТЬ ТА ЕФЕКТИВНІСТЬ В СКЛАДІ КОМБІКОРМІВ ДЛЯ КОРОПА}

\section{Анотація}

У статті представлений новий сировинний компонент у комбікормі для коропа - кормовий концентрат із відходів круп'яних виробництв. В основі кормового концентрату використовуються круп'яне борочно - пшеничне, горохове, ячмінне, а також пшеничні висівки та нелущене зерно вівса. Кормовий конщентрат збалансований за потребами коропа і може 
використовуватися як корм для коропа замість зерна пшениці або у складі комбікормів для коропа. Підібрані параметри вологотеплової обробки та екструдування з метою максимального збереження незамінних амінокислот у складі кормового концентрату. Вологотеплова обробка комбікорму перед екструдуванням - це один з основних етапів, що забезпечують надалі стабільність протікання технологічних прочесів і кінцеву якість кормового концентрату. Був визначений амінокислотний склад за різних температур кормового концентрату після вологотеплової обробки +40, 60, 70 та $80{ }^{\circ} \mathrm{C}$ при постійній вологості концентрату 28,2\%. Розрахований амінокислотний скор для кормових концентратів, які пройшли різну термічну обробку. Амінокислотний скор розраховували по відношенню до потреби коропа в незамінних амінокислотах. Отримано, щчо підвищення температури концентрату в процесі вологотеплової обробки, призводить до зниження вмісту незамінних амінокислот, наприклад, сумарний вміст метіоніну $і$ иистейну у складі кормового концентрату при температурі $+75^{\circ}$ C склало 0,46\%, при мінімально допустимому сумарному вмісті ичих амінокислот у складі кормів 0,5\%. Проведення вологотеплової обробки при температурі продукту вище $+75^{\circ}$ С призводить до зниження вмісту незамінних амінокислот та біологічної иінності кормового концентрату.

Вивчено прочес екструдування кормового концентрату з відходів круп'яних виробництв. Було вивчено вміст глюкози в кормовому концентраті при різних режимах екструдування. Вміст глюкози показує ступінь модифікації крохмалю в прочесі екструдування, $і$ чим більше глюкози містить продукт, тим краще він засвоюється коропом. При екструдуванні з підвищенням температури крохмаль переходить у в'язко-плинний (клейстеризований) стан, утворюючи так званий розплав, охолодження якого призводить до утворення тривимірної сітки гелю. Гранула кормового концентрату стає монолітною структурою, має високу твердість $і$ здатна завдати шкоди кишечнику коропа. Тому як компонент здатного послабити гранулу кормового концентрату, у його складі використані пшеничні висівки в кількості 1\%. Ступінь деструкиії крохмалю у складі екструдованого кормового кончентрату при додаванні пшеничних висівок призводить до того, що гранула стала пористою, твердість ї̈ зменшилася. Встановлено, щңо при підвищенні температури кормового концентрату після екструдування вище $+100^{\circ}$ С біологічна иінність кормового концентрату падає, $і$ він стає незбалансованим за вмістом таких незамінних амінокислот як лізин, треонін, метіонін і цистеїн. Оптимальною температурою продукту після екструдування є температури $+90-100^{\circ} \mathrm{C}$.

Було визначено ефективність екструдованого кормового концентрату у складі гранульованого комбікорму для двох та трьохліток коропа. Кормові коефіцієнти комбікорму, що містить кормовий концентрат у своєму складі 0,9 од., що на 64\% нижче в порівнянні з контрольним комбікормом, що містить зернову групу у свосму складі неекструдовану $і$ не збалансовану за потребою коропа.

Ключові слова: кормовий концентрат, кормове борошно, овес, короп, екструдування, гранулювання, вологотеплова обробка, амінокислотний скор.

1. Шариунов, В.А. Комбикорма и кормовые добавки[Текст] / В.А. Шариунов, Н.А. Попков, Ю.А. Пономаренко и др. - Мн.: «Экоперспектива», 2002. - 440 c.

2. Абросимова, Н. А. Кормовое сырье для объектов аквакультуры[Текст]/ Н.А. Абросимова, С.С. Абросимов, Е.М. Саенко. - Ростов-на-Дону: Эверест, 2005. - 144 с.

3. Никифорова, Т.А. Перспективы использования вторичного сырья крупяных производств[Текст]/ T.А. Никифорова, С.М. Севериненко, Д.А. Куликов // Хлебопродукты. - 2009. - №7. - С.50-51.

4. Егоров, Г.А. Технология муки, крупы и комбикормов [Текст] / Г.А. Егоров, Е.М. Мельников, Б.М. Максимчук. - М. Колос, 1984. - 376 c.

5. Елеонский, А.Н. Прудовое рыбоводство: Допущ. ВКВШ при СНК СССР в качестве учебника для втузов рыб. промсти / д-р биол. наук, проф. А. Н. Елеонский ; Моск. техн. ин-т рыб. хоз-ва и пром-сти им. А. И. Микояна. - Москва : Пищепромиздат, 1946 (Ленинград : Тип. "Печатный двор"). - 325 c.

6. Томмэ, М.Ф. Аминокислотный состав кормов / М. Ф. Томмэ, проф., Р. В. Мартыненко, канд. с.-х. наук ; Всесоюз. акад. с.-х. наук им. В. И. Ленина. Отд-ние животноводства. Всесоюз. науч.-исслед. ин-т животноводства. Москва : Колос, 1972. - 288 с.; 22 см.

7. Кошак, Ж.В. Новая крупяная добавка из отходов крупяного производства для сеголетков карпа / Ж.В. Кошак, Н.В. Зенович, А.Э. Кошак // Пищевая промышленность: наука и технологии. - 2019. - №4(46). - Том 12. - С. 38-48.

8. Дарманьян, П.М. Проблемы регулирования качества гранулированных комбикормов и их компонентов / П.М. Дарманьян// ЦНИИТЭИ хлебопродуктов. - Сер. Комбикормовая промыиленность.-1993.-52 с.

Received 21.04.2021

Reviewed 07.05.2021

\section{Revised 21.06.2021}

Approved 24.06.2021

\section{Cite as Vancouver Citation Style}

Koshak J., Zenovich N., Rybkina E. The impact of production treatments of feed concentrate produced from waste of cereal production on its biological value and efficiency in the composition of compound feed for carp. Grain Products and Mixed Fodder's, 2021; 21 (2, 82): 45-50. DOI https://doi.org/10.15673/

\section{Cite as State Standard of Ukraine 8302:2015}

The impact of production treatments of feed concentrate produced from waste of cereal production on its biological value and efficiency in the composition of compound feed for carp Koshak J. et al. // Grain Products and Mixed Fodder's. 2021. Vol. 21, Issue 2 (82). P. 45-50. DOI https://doi.org/10.15673/

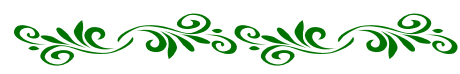

